\title{
MINERALOGICAL COMPOSITION AND FABRIC AS RELATED TO THE MECHANICAL BEHAVIOR OF THE FINE - GRAINED PLIO-PLEISTOCENE SEDIMENTS OF ACHAIA, GREECE
}

\author{
Kouki A. ${ }^{1}$ \\ ${ }^{1}$ Ministry of Public Works, EYDE - Motorway PATHE, Alexandras Av. 205, Athens, Greece, \\ kouki.nassia@gmail.com
}

\begin{abstract}
The fine grained sediments of the Plio-Pleistocene deposits of Achaia have been distinguished into two geotechnical units, stratigraphically successive, the Upper and the Lower one. A number of tests were performed in samples from both units in order to determine their mineralogical composition and fabric, as well as their $\mathrm{CaCO}_{3}$ content. From these it is shown that the two units present main differences in mineralogical composition, type and percentage of clay minerals, concretion ratio and calcium carbonate content, which directly affect their mechanical behavior in construction of technical works.
\end{abstract}

Key words: Upper Geotechnical unit, Lower Geotechnical unit, Mineralogical composition and fabric, Calcium carbonate content.

\section{Introduction}

The fine-grained facies of the Achaia Plio-pleistocene sediments (Kouki, 2006; Kouki and Rozos, 2010), which can be generally termed as "Marls" and belong to Neogene sediments, were distinguished into two separate units, the Upper and Lower one, based at first on engineering geological - geotechnical criteria. However, there was the need to further confirm this distinction, concerning their structure criteria. To this direction, detailed microscopic-mineralogical analysis was performed, as well as determination of $\mathrm{CaCO}_{3}$ content, while laboratory tests (soil classification and mechanical parameters tests) had already been performed in all samples.

The above analyses led to the determination of the mineralogical composition (semi-quantitative analysis) and structure of both units, as well as to the identification of the type and percentance of clay minerals, $\mathrm{CaCo}_{3}$ distribution and the role of aggregations.

It has to be mentioned that in Greece, marls are mainly of Meiocene to Pliocene age, marine or lacustrine origin and in many cases they contain macro and micro-fossils, as well as leaves and coal beds, while their degree of diagenesis differs from site to site.

Many researchers have studied the structure and engineering behaviour of marls in Greece (Kavounidis, 1980; Lupini et al, 1980; Sotiropoulos, 1982; Dounias et al., 1985; Kavounidis, 1985; Theofanopoulos and Theofanopoulos, 1985; Gasios and Christodoulias, 1988; Kavounidis, 1988; Kavounidis et al., 1988; Tsiambaos and Christoulas, 1988; Rozos, 1989; Tsiambaos, 1988; Tsifoutidis, 1993; Christodoulopoulou, 2000). 


\section{Petrographical - mineralogic analyses and physico-mechanical properties of the formations}

\subsection{Research - Results}

The first attempt to determine the mineralogical composition of these formations was made along with the construction of Bozaitika Tunnel. Fifteen (15) soil samples (D1-D6 and D108 - D116) were collected from two sites (ch. $2+380$ and ch. $2+640$ ) and tested. Soil classification tests were performed in all these samples, along with some mechanical tests to estimate shear strength parameters. Mineralogical analysis was applied in three of these samples, while $\mathrm{CaCO}_{3}$ content was determined in all of them. The results are shown in Table 1.

From the evaluation of these laboratory test results the following conclusions can be drawn:

- According to their texture (grain size distribution) and the Atterberg Limits the formations can be classified in the following categories (Table 2).

- Based to the results shown in Tables 1 and 2 it can be concluded that there is correlation between $\mathrm{CaCO}_{3}$ and clay minerals content, as well as sand content. It was observed that $\mathrm{CaCO}_{3}$ content is reduced as we go from marls - clayey marls $(\mathrm{CH}, \mathrm{CL})$ to more sandy - silty formations (CL-ML, $\mathrm{ML})$ and even more to sandy horizons (SC, SM)

- By correlating $\mathrm{CaCO}_{3}$ content and cohesiveness it can be shown that more cohesive soils present

Table 1. Laboratory tests results for all samples.

\begin{tabular}{|c|c|c|c|c|c|c|c|c|c|c|c|c|c|}
\hline \multirow{2}{*}{$\begin{array}{c}\text { Sample } \\
\text { No }\end{array}$} & \multirow{2}{*}{$\begin{array}{c}w \\
(\%)\end{array}$} & \multirow{2}{*}{$\begin{array}{c}\text { Wet unit } \\
\text { weight } \\
\left(\mathrm{gr} / \mathrm{cm}^{3}\right)\end{array}$} & \multicolumn{3}{|c|}{$\begin{array}{c}\text { Grain size } \\
\text { distribution }\end{array}$} & \multicolumn{3}{|c|}{ Atterberg Limits } & \multicolumn{2}{|c|}{$\begin{array}{c}\text { Triaxial test } \\
\text { UU }\end{array}$} & \multirow{2}{*}{$\begin{array}{c}\text { UCS } \\
(\mathbf{K P a})\end{array}$} & \multirow{2}{*}{$\underset{\%}{\mathrm{CaCO}^{3}}$} & \multirow{2}{*}{$\begin{array}{l}\text { AUSCS } \\
\text { Classifi- } \\
\text { cation }\end{array}$} \\
\hline & & & $\begin{array}{c}\text { Sand } \\
(\%)\end{array}$ & $\begin{array}{l}\text { Silt } \\
(\%)\end{array}$ & $\begin{array}{r}\text { Clay } \\
(\%)\end{array}$ & $\begin{array}{l}\text { LL } \\
(\%)\end{array}$ & $\begin{array}{l}\text { PL } \\
(\%)\end{array}$ & $\begin{array}{c}\text { PI } \\
(\%)\end{array}$ & $\begin{array}{c}c \\
(\mathbf{K P} \alpha)\end{array}$ & $\phi^{\circ}$ & & & \\
\hline D1 & 23.2 & 2.16 & 47.0 & 25.0 & 28.0 & \multicolumn{3}{|c|}{ NP } & - & - & 78 & 9.7 & $\mathrm{ML}$ \\
\hline D2 & - & - & 47.0 & 24.0 & 29.0 & NP & - & - & - & 9.0 & & & ML \\
\hline D3 & 11.7 & - & 12.0 & 79.0 & 9.0 & 25.0 & 18.0 & 7.0 & 150 & 39 & - & 20.5 & $\mathrm{CL}$ \\
\hline D4 & 18.0 & 2.25 & 3.0 & 78.0 & 19.0 & 38.0 & 21.0 & 17.0 & 370 & 16 & 634 & 21.5 & $\mathrm{CL}$ \\
\hline D5 & 18.1 & 2.32 & 10.0 & 70.0 & 20.0 & 36.0 & 20.0 & 16.0 & 410 & 13 & 870 & 13.0 & $\mathrm{CL}$ \\
\hline D6 & 25.0 & 2.14 & 12.0 & 72.0 & 16.0 & \multicolumn{3}{|c|}{ NP } & 80 & 22 & 133 & 7.5 & $\mathrm{CL}$ \\
\hline D108 & 29.8 & - & 7.0 & \multicolumn{2}{|c|}{93.0} & 50.0 & 25.0 & 25.0 & 400 & 26 & - & 37.5 & CL \\
\hline D109 & - & - & 7.0 & \multicolumn{2}{|c|}{93.0} & 24.3 & 2.09 & & - & - & 1358 & 35.0 & CL \\
\hline D110 & 23.0 & 2.22 & 3.0 & 67.0 & 30.0 & 35.0 & 18.0 & 17.0 & 350 & 14 & 579 & 6.5 & $\mathrm{CL}$ \\
\hline D111 & - & - & 6.0 & 72.0 & 22.0 & 55.0 & 28.0 & 27.0 & - & - & - & 37.5 & $\mathrm{CH}$ \\
\hline D112 & - & - & 6.0 & 57.0 & 37.0 & 56.0 & 26.0 & 30.0 & - & - & - & 25.0 & $\mathrm{CH}$ \\
\hline D113 & - & - & 4.0 & 60.0 & 36.0 & 51.0 & 27.0 & 24.0 & - & - & - & 21.0 & $\mathrm{CH}$ \\
\hline D114 & - & - & 4.0 & 66.0 & 30.0 & 50.0 & 27.0 & 23.0 & - & - & - & 25.0 & $\mathrm{CL}$ \\
\hline D115 & - & - & 4.0 & 67.0 & 29.0 & 55.0 & 27.0 & 28.0 & - & - & - & 38.0 & $\mathrm{CH}$ \\
\hline D116 & - & - & 5.0 & 64.0 & 31.0 & 59.0 & 28.0 & 31.0 & - & - & - & 29.0 & $\mathrm{CH}$ \\
\hline
\end{tabular}


Table 2. Laboratory tests results of Table 1 samples, summarized in three soil classification categories $(\mathrm{CH}, \mathrm{CL}, \mathrm{ML})$.

\begin{tabular}{|c|c|c|c|c|c|c|c|}
\hline & Sand \% & Silt \% & Clay \% & LL & PL & PI & CaC0 $_{3} \%$ \\
\hline CH & $4-6$ & $57-72$ & $22-37$ & $51-59$ & $26-28$ & $24-31$ & $21-38$ \\
\hline CL & $3-12$ & $67-79$ & $9-30$ & $25-50$ & $18-27$ & $7-23$ & $7.5-37.5$ \\
\hline ML & 47 & $24-25$ & $28-29$ & NP & NP & NP & $9-9.7$ \\
\hline
\end{tabular}

higher contents of carbonate minerals. In this case, shear strength parameters (c and $\phi)$, as well as uniaxial compressive strength are relatively higher.

- As far as their mineralogical composition is concerned, samples classified as clayey marls or argillaceous marls - marls mainly consisted of calcite, clay minerals and quartz. On the contrary, in more sandy or silty samples (sandy silts to sands) quartz dominates, where it is found in the form of small grains of equal size to very small grains in sand material. In the so called clayey marls, rarely relatively bigger grains of quartz can also be found, arbitrarily dispersed in the soil mass.

- Calcite's content decreases as sand's increases, but is also relatively high in the clayey materials.

- The dominant clay minerals are illite and in a smaller percentage montmorillonite. These minerals along with calcite constitute the main matrix of the formations. The clay minerals content decreases as sand's portion increases.

- Finally, chorite, micas (moschovite, serikite and less often biotite) and albite are also present in small quantities, while in more sandy samples Fe-hydroxides can also be found, due to increased permeability and easier therefore infiltration of water.

After the distinction of these sediments into two separate geotechnical units, the Upper and the Lower one, there was the need to repeat the mineralogical analyses in samples from both units. For that purpose seven (7) samples were used, two (2) from the Upper unit (D24, D27), one from the Intermediate unit (D17) and four from the Lower unit (D121, D125, D130 and D134). In all samples More specifically, mineralogical and petrographic analyses were performed in the Mineralogy Petrography Laboratory of IGME and the Laboratory of Minerals and Rocks of Patras University, by using: a) the optical method under polotic and stereoscopic microscope and b) the X-ray perithlasimetry method (XRD). Semi-quantitative analysis was done by using EVA 6.0 software and ICPDS database. Calcite's content was measured after removing content of carbonates, while montmorillonite content with the method of methylene blue.

In Table 3 the results of mineralogical analyses are presented, while in Table 4 the physical and mechanical properties of the tested samples.

From all the above analyses and the tests performed the following can be recorded for each sample:

\section{$\underline{\text { Sample D17 }}$}

According to soil-classification tests this sample is classified as CL, while from the mineralogical analysis as marly clay. It belongs to the Intermediate unit (from the Lower to the Upper unit) and according to $\mathrm{CaCO}_{3}$ content, it is classified as a clay-marl (Photo 1).

$\underline{\text { Sample D24 }}$

It is classified as ML, while from the mineralogical analysis as silicaceous micro-sandstone. It be- 
Table 3. Mineralogical composition of the samples (semi-quantitative analysis)

\begin{tabular}{|c|c|c|c|c|c|c|c|}
\hline Sample & Quartz & Calcite & Albite & Illite & Kaolinite & Chlorite & Montmorillonite \\
\hline D17 & 23 & 20 & 6 & 26 & 13 & 4 & 8 \\
\hline D24 & 39 & 11,6 & 14 & 16 & 7 & 5 & 6,8 \\
\hline D27 & 37 & 15 & 12 & 16 & 8 & 6 & 5,2 \\
\hline D121 & 18 & 35 & 5 & 10 & 18 & 3 & 10,8 \\
\hline D125 & 22 & 30 & 6 & 15 & 14 & 3 & 9,6 \\
\hline D130 & 32 & 22,6 & 6 & 14 & 13 & 4 & 8,4 \\
\hline D134 & 31 & 21,6 & 13 & 15 & 9 & 5 & 5,2 \\
\hline
\end{tabular}

Table 4. Results of soil materials laboratory tests.

\begin{tabular}{|c|c|c|c|c|c|c|c|c|c|c|c|c|c|}
\hline \multirow[b]{2}{*}{ Sample } & \multirow[b]{2}{*}{$\begin{array}{c}\mathrm{W} \\
(\%)\end{array}$} & \multirow{2}{*}{$\begin{array}{l}\text { Spec. } \\
\text { weigh }\end{array}$} & \multicolumn{2}{|c|}{ Unit weight } & \multicolumn{3}{|c|}{ Grain size distribution } & \multicolumn{3}{|c|}{ Atterberg Limits } & \multicolumn{2}{|c|}{ Triaxial test UU } & \multirow[b]{2}{*}{ AUSCS } \\
\hline & & & $\begin{array}{c}\text { Wet } \\
\left(\mathrm{gr} / \mathrm{cm}^{3}\right)\end{array}$ & $\begin{array}{c}\text { Dry } \\
\left(\mathrm{gr} / \mathrm{cm}^{3}\right)\end{array}$ & $\begin{array}{l}\text { Sand } \\
(\%)\end{array}$ & $\operatorname{Silt}(\%)$ & $\begin{array}{l}\text { Clay } \\
(\%)\end{array}$ & $\operatorname{LL}(\%)$ & PL $(\%)$ & $\operatorname{PI}(\%)$ & $c(\mathbf{K P} \alpha)$ & $\phi$ & \\
\hline D17 & 17,73 & 2,68 & 21,50 & 18,26 & 1,76 & 73,13 & 25,11 & 32,83 & 20,95 & 11,88 & 648,7 & 4,74 & $\mathrm{CL}$ \\
\hline D24 & 14,76 & 2,64 & 20,90 & 18,21 & 1,90 & 83,22 & 14,88 & 31,82 & 20,69 & 11,13 & 207,3 & 23,54 & CL \\
\hline D27 & 10,78 & 2,63 & 20,20 & 18,23 & 34,22 & 58,04 & 7,74 & 20,09 & 16,43 & 3,66 & 182,6 & 13,77 & ML \\
\hline D121 & 17,82 & 2,72 & 1,89 & 1,6 & 1,4 & 63,46 & 35,14 & 33,89 & 15,87 & 18,02 & 141,6 & 16,6 & CL \\
\hline D125 & 15,17 & 2,72 & 2,11 & 1,83 & 1,21 & 58,55 & 40,24 & 32,97 & 15,43 & 17,54 & 106,1 & 31,2 & $\mathrm{CL}$ \\
\hline D130 & 14,87 & 2,71 & 2,22 & 1,93 & 1,77 & 76,78 & 21,25 & 28,6 & 18,77 & 9,83 & 182,9 & 28,45 & CL \\
\hline D134 & 8,58 & 2,67 & 2,05 & 1,89 & 10,55 & 71,4 & 18,05 & 23,1 & 17,56 & 5,54 & 42,61 & 22,97 & CL-ML \\
\hline
\end{tabular}

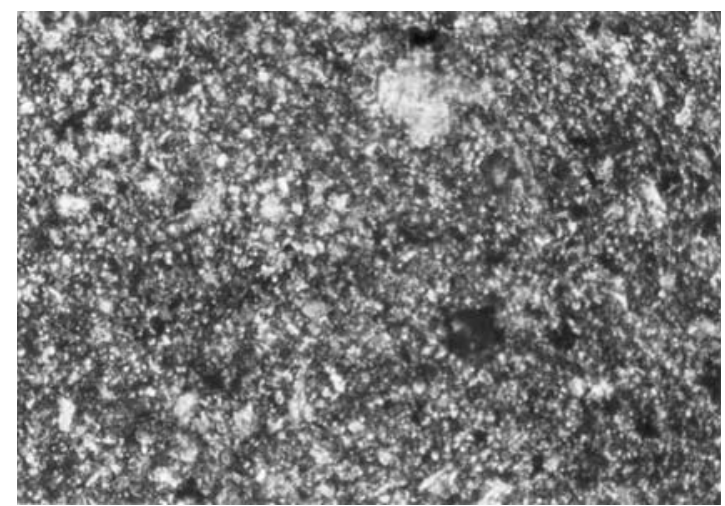

Photo 1: Sample D17. Quartz and zircon in calcite (Nicols+, length $250 \mu$ ). 


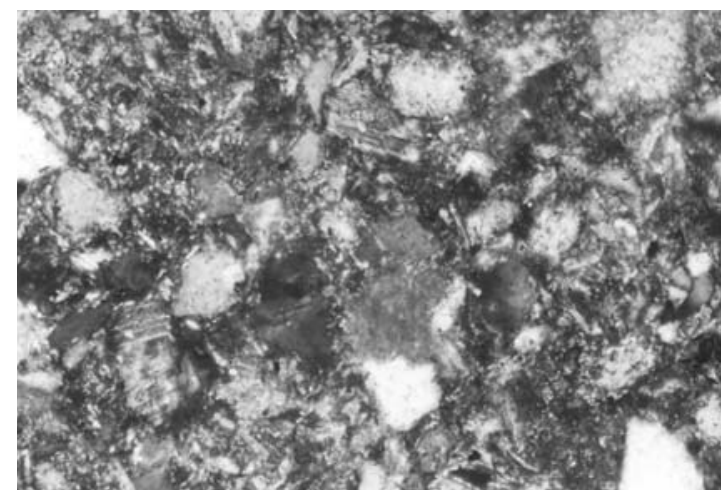

Photo 2: Sample D24. Quartz, moschovite, calcite and feldspar. Matrix material is calcite (Nicols+, length $250 \mu$ ).

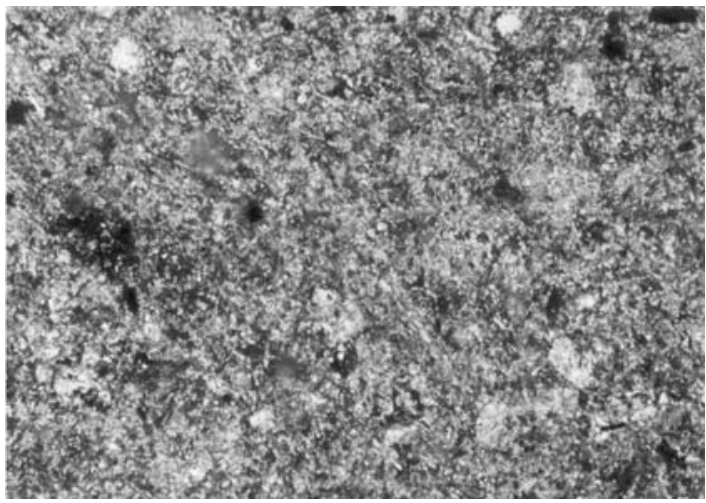

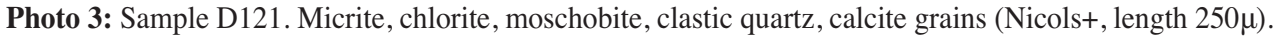

longs to the Upper Geotechnical unit and according to $\mathrm{CaCO}_{3}$ content, it is classified as a marly clay (Photo 2).

\section{Sample D27}

It is classified as ML, while from the mineralogical analysis as silicaceous micro-sandstone. It belongs to the Upper Geotechnical unit and can not be classified according to $\mathrm{CaCO}_{3}$ content as a non argillaceous sediment.

\section{Sample D121}

It is classified as CL, while from the mineralogical analysis as marly clay. It belongs to the Lower Geotechnical unit and according to $\mathrm{CaCO}_{3}$ content, it is in the limit between clayey marls and marls (Photo 3).

\section{$\underline{\text { Sample D125 }}$}

It is classified as CL, while from the mineralogical analysis as marly clay. It belongs to the Lower Geotechnical unit and according to $\mathrm{CaCO}_{3}$ content, it is classified as a clayey marl.

\section{$\underline{\text { Sample D130 }}$}

According to soil-classification tests this sample is classified as CL, while from the mineralogical analysis it is classified as silicaceous mudstone. It belongs to the Lower Geotechnical unit and according to $\mathrm{CaCO}_{3}$ content, as a clayey marl. 


\section{$\underline{\text { Sample D134 }}$}

It is classified as CL-ML, while from the mineralogical analysis as silicaceous micro-sandstone with thin mudstone sub-layers. It belongs to the Lower Geotechnical unit and according to $\mathrm{CaCO}_{3}$ content, it is classified as a clayey marl.

By assessing all the above it can be concluded that:

- All samples tested are cohesive, with small to medium porosity and with few small fissures.

- Samples D24 and D27 of the Upper Geotechnical unit have a light yellow color, fine -sandy texture and increased content of quartz (37-39\%), which is also illustrated in the grain-size analysis, where the total contents of sand and silt are $85 \%$ and $92 \%$ respectively, while the clay percentage is $15 \%$ and $8 \%$. On the contrary, according to the mineralogical analysis (semi-quantitative analysis) the clay minerals content for each sample is approximately $35 \%$, which confirms the presence of aggregations. It is noted that sample D27, with higher sand content and lower silt content than sample D24, presents greater aggregation. More specifically, the Aggregation ratio (Ar) is 2.62 and 4.52 for the two samples respectively.

As far as the clay minerals are concerned, illite is the dominant one (16\%), while kaolinite (7-8\%), montmorrilonite (5-7\%) and chlorite (5-6\%) are also present. Calcite's content is between $11.5 \%$ and $15 \%$. In general, these samples contain more quartz and albite and less calcite and clay minerals than the rest of the samples.

- Sample D17 belongs to the Intermediate Geotechnical unit and therefore has properties from both units, Upper and Lower. It has light yellow color, smooth, non-brittle texture and leptocrystallicpelitic structure. It doesn't have clear bedding, while it contains fossils and shell fragments and presents signs of bio-disturbance. Quartz percentage is less (23\%) in comparison to the previous samples, which in the grain-size analysis corresponds to high silt content $(73 \%)$, when sand is only $1.76 \%$. Clay content is also high $(25 \%)$, while from the mineralogical analysis the clay minerals content is $51 \%$ and the aggregation ratio $\mathrm{Ar}=2.0$. Calcite's content is also high (20\%). The dominant clay mineral is illite (26\%), kaolinite is $13 \%$, monmorillonite is $8 \%$ and chlorite $4 \%$.

- Samples D121, D125, D130 and D135 of the Lower Geotechnical unit not only have significant differences comparing to the samples of the Upper Unit, but also present differences among them, which clearly shows that in marls, clay-marls and clayey marls that belong to the Lower unit there can also be found intermediate types at places, mainly of silty composition or with silty intercalations. The existence of these intermediate types does not in any case alter the clayey marly nature of the Lower unit formations

Thus, samples D121 and D125 are of light gray color and belong to the typical clayey marls, with small sand percentages $(1,4$ and 1,2\%), reduced silt content $(63.5 \%$ and $58,5 \%)$ and higher clay one (35\% and $40 \%$ respectively). Quartz percentage is only $18 \%$ and $22 \%$ for the two samples, while calcite is $35 \%$ and $30 \%$ respectively. Kaolinite is the dominant clay mineral (18 and 14\%), followed by illite (10 and 15\%), montmorillonite, which presents greater values than the rest of the samples (10,8 and $9.6 \%$ respectively) and at last chlorite with around $3 \%$. The total clay minerals content for both samples is approximately $42 \%$ and thus the aggregation ratio is 1.20 and 1.05 respectively. It has to be mentioned that these samples differ from sample D17 of the Intermediate unit, as far as Ar and clay minerals content are concerned, even though they have the same structure (klastic) and texture (solid).

Samples D130 and D134, of the Lower also unit, differ from the typical clayey marls (D121 and D125) and are characterized as clay-marls, mainly due to the increased silt content (77\% and $71.5 \%$ 
respectively) and the smaller clay one (21\% and $18 \%)$ and therefore the increased quartz content (32\% and 31\%) and decreased clay minerals content (32\% and 31\%), as shown from the mineralogical analyses. The Aggreration ratio is 1.84 and 1.88 respectively. Calcite content is also low (21.6\% and 22\%). The dominant clay mineral is illite, followed by kaolinite and montmorillonite according to their relative contents. The above declare that samples D130 and D134 belong basically to the intermediate types in the Lower unit mentioned above.

From the above it is concluded that the clear division of these fine-grained sediments into separate geotechnical units, of distinct composition, structure and mechanical behavior can only be done by the correlation of field observation, microscopic - mineralogical analyses and laboratory soil materials tests.

\section{Conclusions}

There is a correlation in the percentage of calcium carbonate content with the clay and sand content, as this decreases from marls-clayey marls (CH, CL) to sandy-silts (CL-ML, ML), and further more in the sandy layers SC, SM.

From the correlation of the percentage of calcium carbonate content with the cohesiveness of the samples it can be seen that the most cohesive samples present increased contents of carbonic minerals.

As far as the mineralogical composition is concerned, samples which are classified as clayey marlsmarls mainly contain calcite, clay minerals and quartz. On the contrary, samples that contain high percentage of sand and silt (from sandy silts to sands) present increased quartz percentages, in a way that quartz can constitute their main component.

As far as the clayey minerals are concerned, mainly illite and in a smaller content montmorillonite are recorded, which compose, along with calcite, the conjunctive material of these sediments. The percentage of these minerals decreases with the increase of sand content.

Upper Geotechnical unit samples have light-yellow color and fine grained sandy texture, increased quartz content, and clay fraction from mineralogical analysis roughly around 35\%, indicative of the existence of concretion (the concretion ratio ranges among 2.62 to 4.58).

Lower Geotechnical Unit samples are noticeably differentiated both from those of the Upper Unit, as well as from those of their own unit, since intermediary types of silt composition or silt layers prevail at places. Thus, the common clayey marls appear with decreased sand contents and increased clay contents. Samples from Lower unit that comprise intermediate types and are characterized as clayey marls have higher percentages of silt, lower percentages of clayey fraction, while from mineralogical analysis quartz percentage was found higher, clayey mineral percentage lower, and the concretion ratio ranges from 1.84 to 1.88 .

\section{References}

Gasios, E. \& Christodoulias, I., 1988. Investigations for the damages of the National Route Athens - Salonika, Km 70+000 - Km 90+000 due to expansive soil. Bulletin of Geological Society of Greece, Vol. $\mathrm{XX} / 3, \mathrm{p} .133-145$.

Gasios, E., Christodoulias, I., 1988. Mechanical behavior of expansive marls in Thiva's field. Proceedings of the $1^{\text {st }}$ Hellenic Congress of Geotechnical Engineering, TEE - HSSMGE, T-1, Athens, p. 33-36.

Theophanopoulos, P. x $\alpha$ Theophanopoulos, N., 1985. Mechanical behaviour of marly formations under 
Electronic Microscope "Scanning". Proceedings of the $2^{\text {nd }}$ Hellenic Conference of Geotechnical Engineering "Foundation design parameters", HSSMGE, Athens, p. 321-330.

Kavounidis, S., 1980. Some remarks from the investigation of marls. Technical Chronicles, 2, p. 24-27.

Kavounidis, S., 1985. Geotechnical consideration of marly formations. Proceedings of Conference "Geotechnical problems of Piraeus marls", TEE, Athens, p. 23-64.

Kavounidis, S., 1988. A proposal for common approach of the mechanical behavior of marls. Proceedings of the $1^{\text {st }}$ Hellenic Congress of Geotechnical Engineering, TEE, T.3, Athens, p. 191-192.

Kavounidis, S., Tika, Th., Dounias, G.Th., 1988. Greek marls under the microscope. Proceedings of the

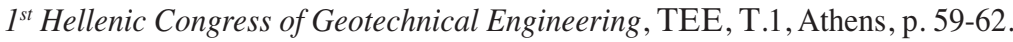

Kostopoulos, S., 1988. Geotechnical consideration of marly formations in Greece. Proceedings of the $1^{\text {st }}$ Hellenic Congress of Geotechnical Engineering, TEE - HSSMGE, T-1, Athens, p. 63-68.

Kouki A., 2006. Engineering geological - geotechnical parameters and mechanical behavior of hard soils and soft rocks in the design of underground works. PhD Thesis, University of Patras.

Kouki, A. and Rozos, D., 2010a. Engineering geological - geotechnical conditions in the wider area of Patras ring - road. Compilation of the relevant map at a scale of 1:5000. Proceedings of the $12^{\text {th }}$ International Congress of Geological Society of Greece, Patras, May, 2010.

Kouki,A. and Rozos, D., 2010b. The fine-grained Plio-pleistocene deposits in Achaia - Greece and their distinction in characteristic geotechnical unities. Proceedings of the $12^{\text {th }}$ International Congress of Geological Society of Greece, Patras, May, 2010.

Lupini, J.F. Hight, D.W., Cavounidis, S., 1980. Some observations of microfabric and their role in understanding soil behavior. Rivista Italiana di Geotecnica, Anno XIV-N.2

Dounias, G., Tika, Th., Kavounidis, S., 1985. Some observations of microfabric of marls of Piraeus. Proceedings of Conference "Geotechnical problems of Piraeus marls", TEE, Athens, p. 171-184.

Rozos, D., 1998. Engineering Geological conditions in Achaia County. Geomechanical characteristics of Plio-pleistocene sediments. PhD Thesis, University of Patras, 453p.

Sotiropoulos, I., 1982. Marls. Proceedings of the $1^{\text {st }}$ Hellenic Geotechnical Conference, HSSMGE, Athens, p. 243-266.

Tsiambaos, G., Christoulas, S., 1988. Mechanical behavior of marls in Iraklion, Crete. Proceedings of the $1^{{ }^{s t}}$ Hellenic Congress of Geotechnical Engineering, TEE - HSSMGE, T-1, Athens, p. 109-112.

Tsiambaos, G., 1988. Engineering geological characteristics of marls in Iraklion, Crete. PhD Thesis, University of Patras.

Tsifoutidis, G., 1993. Intrinsic properties of Hellenic marls. Ph.D Thesis. University of Durham. United Kingdom.

Christodoulopoulou, T., 2000. Microstructure of the fine grained Neogene - Pliopleistocene sediments of North Peloponnese, in relation to their physical and mechanical properties. PhD Thesis, University of Patras. 